\title{
THE MEAN TIME TO FAILURE OF HIGH TEMPERATURE THERMOCOUPLES IN IRRADIATION CAPSULES
}

\author{
by \\ F. K. Jacobsen
}

This report was prepared as an account of work sponsored by the United States Government. Neither the United States nor the United States Energy Research and Development Administration, nor any of their employees, nor any of their contractors, subcontractors, or their employees, makes any warranty, express or implied, or assumes any legal liability or responsibility for the accuracy, completeness or usefulness of any information, apparatus, product or process disclosed, or represents that its use would not infringe privately owned rights.

Work supported by the Atomic Energy

Commission, Contract AT(04-3)-633 and Contract AT(04-3)-167, Project Agreement No. 17. 


\section{DISCLAIMER}

This report was prepared as an account of work sponsored by an agency of the United States Government. Neither the United States Government nor any agency Thereof, nor any of their employees, makes any warranty, express or implied, or assumes any legal liability or responsibility for the accuracy, completeness, or usefulness of any information, apparatus, product, or process disclosed, or represents that its use would not infringe privately owned rights. Reference herein to any specific commercial product, process, or service by trade name, trademark, manufacturer, or otherwise does not necessarily constitute or imply its endorsement, recommendation, or favoring by the United States Government or any agency thereof. The views and opinions of authors expressed herein do not necessarily state or reflect those of the United States Government or any agency thereof. 


\section{DISCLAIMER}

Portions of this document may be illegible in electronic image products. Images are produced from the best available original document. 


\begin{abstract}
This report presents the results of calculations of the mean time before failure of thermocouples as a function of temperature and neutron flux. These thermocouples were used in the performance of in-reactor tests of the coated particle fuel for use in high-temperature gas-cooled nuclear reactors.
\end{abstract}

The results cover 429 type $\mathrm{K}$ chromel-alumel thermocouples tested in an atmosphere of helium and argon gas at temperatures of 300 to $1000^{\circ} \mathrm{C}$, at fast neutron $\left(E>0.18 \mathrm{MeV}\right.$ ) fluxes of $1.44 \times 10^{13}$ to $6.48 \times 10^{14}$, for periods up to 6000 hours. 


\section{CONTENTS}

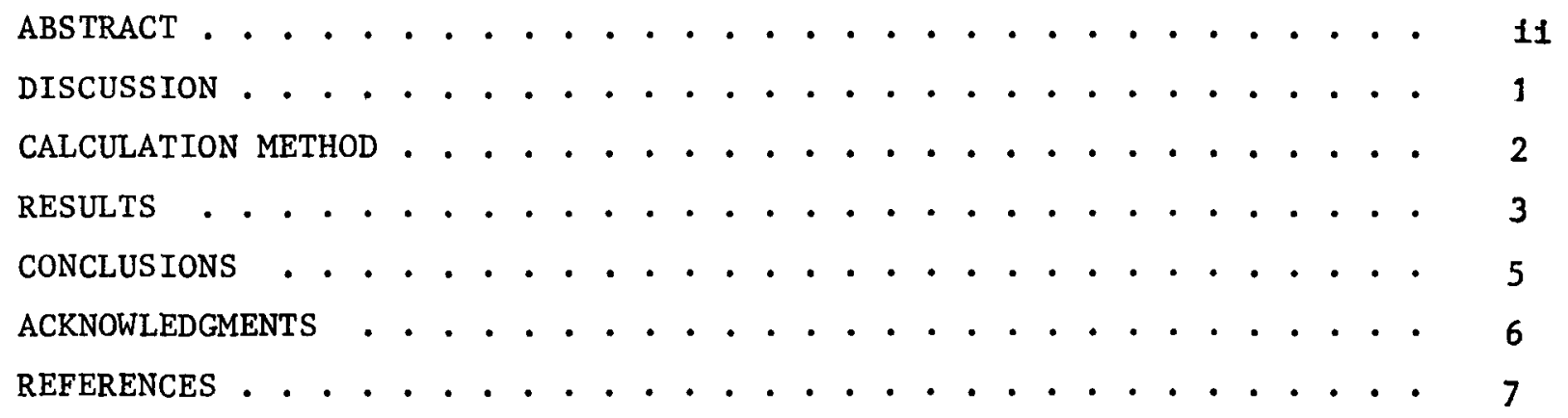




\section{DISCUSSION}

The GA materials development program for the high-temperature gas-cooled reactor (HTGR) requires temperature monitoring for the coated particle fuel and graphite irradiation tests. Because of the condition of the test reactor core, the temperatures fluctuate during a test and must be monttored continuously. An irradiation test may last several thousand hours. The testing was accomplished in the Engineering Test Reactor and the Materials Test Reactor at the National Reactor Test Station at Idaho Falls, Idaho, and in the General Electric Test Reactor at the Vallecitos Nuclear Center, Pleasanton, California.

Sheath-type thermocouples made of three different alloys were used because of their flexibility and compatibility with the particular experiment design. The primary alloy was chromel-alumel (type $\mathrm{K}$ ). The others were tungsten-rhenium alloys: $\mathrm{W}-3 \% \operatorname{Re} / \mathrm{W}-25 \% \operatorname{Re}$ and $\mathrm{W}-5 \% \operatorname{Re} / \mathrm{W}-25 \% \operatorname{Re}$. This analysis deals with the chromel-alumel units because more of them were used. The chromel-alumel thermocouples were 1/16 in. in diameter, magnesium oxide insulated, and sheathed in Inconel 600 .

A total of 438 chromel-alumel thermocouples had been used when this analysis was initiated. Since nine were found to have failed during installation before irradiation testing commenced, the calculations cover 429 tested chromel-alumel thermocouples.

Each thermocouple was subjected to quality control and integrity testing before being incorporated into an irradiation capsule. Some pedigree data was recorded before the testing. The data recorded included hours to failure or test completion, test temperatures, and test fast neutron flux. On completion of the test, the fast neutron fluence was calculated for each thermocouple. 
Reference 1 contains an evaluation of the data from the first 242 thermocouples to determine the probability of failure during test.

The effects of all the documented variables on the mean time before failure (MTBF) of 571 thermocouples of all alloys are given in Ref. 2. Of the 571 thermocouples, 285 were chromel-alumel units. The analysis of the chromel-alumel units indicated that temperature and fast neutron flux were the variables having a major influence on $\mathrm{MTBF}$. Increases in either temperature or flux appeared to decrease MTBF, but there was insufficient data to show the effects separately.

The evaluation reported herein is limited to chromel-alume1 thermocouples tested from 400 to $800^{\circ} \mathrm{C}$ because most of the data was in this range. The data was plotted at the median temperatures of 500,600 , and $700^{\circ} \mathrm{C}$. Analysis of the data is continuing and it is anticipated that analysis over wider ranges, other variables, and the tungsten-rhenium alloys can be reported in the future.

\section{CALCULATION METHOD}

An average flux value was derived for each thermocouple by dividing its test fluence by its test hours.

The MTBF was determined from the sum of the test hours and the number of failures of selected groups of thermocouples. The $60 \%$ lower confidence limit was calculated from the relationship

$$
\operatorname{MTBF}=\frac{2 \mathrm{~T}}{\mathrm{x}_{2(\mathrm{r}+1), \alpha}^{2}},
$$

where $\quad T=$ sum of test hours,

$$
\begin{aligned}
r & =\text { number of failures observed, } \\
\alpha & =1-\text { confidence level, } \\
\mathrm{X}^{2} & =\text { chi-square distribution, } \\
2(\mathrm{r}+1) & =\text { degrees of freedom for } \mathrm{X}^{2} .
\end{aligned}
$$


The thermocouples selected were tested within a plus and minus range of temperature and flux about a central value. The resulting MTBF was then considered applicable to the combination of central temperature and flux values. Various ranges of temperature and flux were tried to aid in selecting the ranges that seemed to best depict the continuity and show the differences in the results.

It was found desirable to include thermocouples tested over a temperature range of $\pm 100^{\circ} \mathrm{C}$ and a flux range of $\pm 15 \times 10^{13}$ neutrons $/ \mathrm{cm}^{2}-\mathrm{sec}$. When these relatively large ranges were used to calculate values for points fairly close together, each thermocouple was included in the calculation for many points. For example, when a temperature range of $\pm 100^{\circ} \mathrm{C}$ was used, a particular thermocouple tested at exactly $600^{\circ} \mathrm{C}$ was included, in the appropriate flux range, in the MTBF calculations for $500^{\circ} \mathrm{C}, 600^{\circ} \mathrm{C}$, and $700^{\circ} \mathrm{C}$. This method of calculation reduced the effect of sample variations from one temperature or flux to the next because each sample included significant portions of the adjacent samples. This caused a smoothing of the results, which masked any real, abrupt effects. However, no tendency toward abrupt effects was expected in thermocouple MTBF.

Another effect was derived from the use of large ranges of temperature and flux about the median for which a value was being calculated. As the upper or lower boundary of temperature or flux was approached, one side of the flux and/or temperature range started to have significantly fewer data points in it. The values calculated were affected by the decrease in the number of points and by their bias to one side of the center of the range. Thus, values of MTBF near the temperature or flux limits of the data have to be considered less valid than those near the center.

\section{RESULTS}

The results of the calculations for temperatures of 500,600 , and $700^{\circ} \mathrm{C}$ are presented in Fig. 1. The curves show that within this temperature range the MTBF decreases as the temperature increases. The curves also show that as the neutron flux increases, the MTBF decreases. Further investigation 
reveals that portions of the plotted lines roughly approximate lines of constant fluence. This may be interpreted to indicate that regardless of the flux level, a thermocouple can endure just so much fluence at a given temperature. This supports the concept of materials suffering accumulative damage from neutron bombardment.

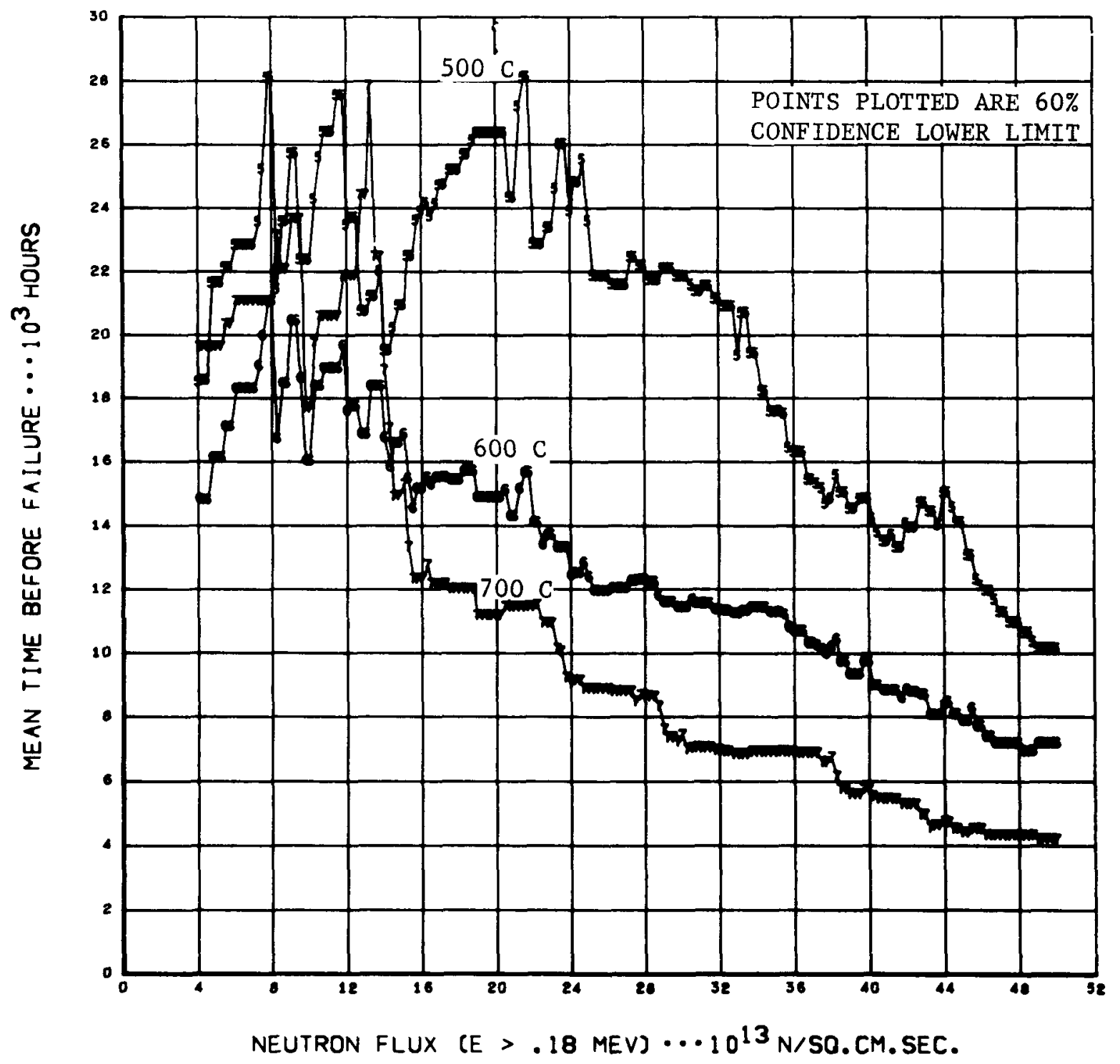

Fig. 1. Mean hours before failure - chromel-alumel thermocouples 


\section{CONCLUSIONS}

The test data accumulated tends to support the concept of accumulative material damage from neutron bombardment, within the range of temperatures and flux of these tests. They also illustrate the effects of temperature on the tolerance to neutron damage of chromel-alumel thermocouples. Continued testing and data evaluation are expected to reinforce these conclusions. 


\section{ACKNOWLEDGMENTS}

Significant contributions to the preparation of this report were made by N. L. Sandefur.

Significant contributions to the development of the thermocouple data analyzed for this report were made by H. F. Bothman, F. D. Carpenter, B. A. Czeck, G. R. Forbes, G. Graeber, C. H. Richards, Jr., L. D. Scott, J. S. Steibel, R. J. Grenda, and J. R. Thompson. 


\section{REFERENCES}

1. Sandefur, N. L., et al., "Reliability of High-Temperature Thermocouples in Irradiation Capsules," Gulf General Atomic Report GA-9653, September 18, 1969.

2. Jacobsen, F. K., N. L. Sandefur, and R. J. Grenda, "Reliability Analysis of High Temperature Thermocouples in Irradiation Capsules," Gulf General Atomic Report Gulf-GA-A10864, October 27, 1971. 